\title{
Reform of World Governance Arrangements on Mining Sectors Based on the Principles of Justice and Sustainability
}

\author{
Rachmad Safa'at \\ Faculty of Law \\ Brawijaya University \\ Malang, Indonesia \\ rachmad.syafaat@ub.ac.id
}

\begin{abstract}
This research aims to analyze the problem of weak world governance in the field of mining in order to provide justice in the economic field of mine management and sustainable environmental stewardship, so that environmental execution can be maintained, and it can minimize the impact of mining exploration. The absence of international regulations governing mining governance, particularly from any organ under the United Nations causes the absence of international standards over mining activities. This leads countries to ultimately implementing various mining rules depending on their own experience and law enforcement. Here it is important to explore whether it is possible to establish certain international rules for mining activities that generally involve developing countries as producing countries and developed countries as investors, given that the management in the mining sector is a business that requires a large cost. Learning from Indonesia's experience, this research will explore some core aspects that have to be regulated in the prospective international rules. Therefore, international guidelines may be found to assist countries in managing their mining laws, especially for developing countries where fair and sustainable development interests are often defeated by economic interests alone. In addition, the international rules on mining will be able to direct the behaviour of multinational companies (MNCs) that mostly comes from developed countries to pay more attention to environmental aspects.
\end{abstract}

Keywords—world governance, mining, justice, sustainability

\section{INTRODUCTION}

The existence of mineral resources contained within the earth is promising to be exploited, as the resources are of high values and not all regions are enriched with mineral content or particular natural resources with high economic values.

Mining exploitation is regarded important for the livelihood in modern time, which is related to energy provision. In a modern civilisation, energy is taken as a basic need of human being in addition to clothes, food, and housing and water.

Mining resources are categorised into non-renewable ${ }^{1}$ natural resources because such resources will never get back to existence when they are running out due to exploitation. Mining deposit commonly found under the earth surface requires excavation further down into the earth to obtain the materials. This excavation leads to significant change in landscape and environment.

Management of natural resources in Indonesia always refers to Article 33 Paragraph (2) and (3) as the legal framework: (2) Sectors of production, which are important for the country and affect the life of the people, shall be under the powers of the State. (3) The land, the waters and the natural resources within shall be under the powers of the State and shall be used to the greatest benefit of the people.

In its implementation, the government acts on behalf of its people. When the mining activities are executed by a contractor, the government acts as a permit issuer to the contractor concerned. The permit is sued by the government is in the form of mining authority, contract of work (CoW), mining agreement, and production sharing contract[1].

Mining development program is aimed to provide industrial raw materials in a home country, optimise exports and state revenue, and provide more job and business opportunities. The development of mining business may involve varying mining yield and efficient yield management[1]. Therefore, the government keeps pushing potential investment especially foreign investment in mining business as fee paid to the state by the company given the mining authority.

Natural resources management often requires as sistance or collaboration with multi-national companies. This requirement leads to cooperation contract between the government and multi-international company regarding the management of natural resources, allowing profit sharing between the government and the company. Such cooperation occurs as part of the potential management in mining and unexplored natural resources in developing countries, and this condition requires another party to help with the management.

One of the impacts of the cooperation is sharing profit and management systemthat often disadvantages the government or a state that has the as set. In other words, the profit is mostly

materials (crude oil and coal) and excavated materials (gold, silver, lead, iron, and many more).
Non-renewable natural resources are defined as those that are not renewable and they are prone to running out when the utilisation is uncontrollable. Usually, non-renewable resources comprise mining 
dominated by the multi-national companies that manage the mining. This is sue surely brings to imbalance in the welfare of the people and loss. Therefore, this research is mainly focused on how international rules are managed to protect developing countries which have natural resources from loss during the management and profit sharing.

\section{NATURAL RESOURCES FOR THE WELFARE OF SOCIETY}

The existence of natural resources is a gift from God that serves as the basic need for human to appropriately cultivate natural resources for the welfare of the people. Such management cannot run alone without as sis tance from another sector that is qualified to use technology for the management. When the foreign sectorinterferes with the mining activities, it brings is sue over profit sharing between the mining manager and the government (state).

The collaboration between the government and another sector is usually regulated in the Contract of Work (CoW) as provided in Article 10 of Law Number 11 of 1967 on the Main Provision of Mining (Old Mining Law), and in the provision of Decree of Minister of Mining and Energy Number 1409.K/201/M.PE/1996 on Procedures in giving mining authority, permit, contract of work in coal mining, in which Article 1 defines the contract of work. Contract of work aims to bring welfare to people. Ismail Sunny defines contract of work as follows: Cooperation of foreign investment in the form of contract of work occurs when foreign investment forms a single legal entity in Indonesia where this legal entity establishes cooperation with another legal entity that uses national capital"[1].

Under Law Number 11 of 1967 on the Main Provisions of Mining ("Old Mining Law"), foreign parties could participate in large-scale mining projects through Contract of Work (CoW) and Coal Contract of Work ("CCoW") whilst relatively small- and medium-scale mining projects could only be conducted by Indonesian national parties by virtue of Mining Licenses ("KPs"). In other words, neither (i) a foreign entity nor (ii) an Indonesian foreign investment company, in which a foreign party is able to legally hold shares ("PMA Company"), could hold a KP under the Old Mining Law. A PMA Company could, however, hold a CoW or a CCoW.

On January 12, 2009, the Old Mining Law was replaced by the 2009 Mining Law. Unlike the Old Mining Law, the 2009 Mining Law allows a Mining Business License ("IUP") to be held by any type of Indonesian business entity, including a PMA Company, without any initial restriction or limitation on share ownership[2].

The management of natural resources requires precaution and justice, as it determines the life of society and welfare. When the management is not appropriately performed, conflict between expectation and implementation will arise, which may result in putting the state legitimacy in jeopardy. Unstoppable conflict may lead to more serious threat not only restricted to demonstration but it also triggers agitation, unfair monopoly over land by people who hope for justice [3].

Ideally, natural resources are managed for societies, in which they are expected to be able to feel the result given by the natural resources management to achieve the welfare for them all. As long as the righteous things are applied, justice will arise[4]. In other words, justice is a representative of righteous values among people. In the discussion over natural resources, Benjamin Wolmen argues that value is a degree of worth or excellence given to or obtained from an object [5].

C.F.G Sunaryati Hartono argues that the fifth sila (principle) is concerning the objective and mission of Indonesia when it was united back in 1928 or when it first held its independence in 1945 when the Republic of Indonesia was formed[6]. Social justice for the entire citizens generally represents the objective of the state of welfare which is based on law (Social Rechtstaat)[6]. Therefore, it is essential to fully understand the sense of social justice. Social justice, thus, should embrace all the communities.

Social justice, as written in the fifth sila (fifth principle) is closely related to the conception of human rights. The concept of social justice is based on the principle of human rights and egalitarianis $m[7]$. This concept takes the higher degree than egalitarianism in economic field, such as progressive tax, income levy, or asset distribution. Therefore, in the practice, social justice is commonly linked to economy[7]. Those policies are expected to provide equal chance and outcome based on the social structure, all of which are meant to break the inequality caused by the implementation of procedural justice system.

The management of natural resources, especially related to mining in a global scope, has not reached the mutual agreement made as the basis of mining management, in which the mining is part of natural resources in the world. As a result, the majority of profit coming from mining products is mostly absorbed by multi-national companies, leaving the state with only remaining profit. This situation certainly needs a regulation or a strong negotiation for higher and fairer sharing profit for the state. For example, smelter was built in the state to process mining materials, and the government warned that the permit of smelter development is prone to revocation [8]. To realise the welfare for all people, strong and brilliant bargaining position to have fairer and better portion of the mining yield is needed. When this is realised, the path to the welfare regarding the equal profit sharing is widely open.

\section{GlobAl MANAGEMENT OF NATURAL RESOURCES}

Global liberalisation and the transformation from government intervention to a market-based system for resource allocation in the 1980s has opened an access for the new generation of mining law and agreements and contracts that stimulate foreign investment. Although it is impossible to find it the same among countries, there is still general tendency in developing countries to renew out-dated laws and to improve efficiency of the process through: application procedure and simplified agreement; renegotiation; improvement of mineral resources agreements; minimising government intervention; improvement of management of mining right delegation; strengthening the principle of security of tenure and; improvement of regulation regarding mining right conveyance.

The legal implementation of mining with this model has resulted in desire to invest in developing countries, which is seen competitive to withdraw foreign investment, and mining 
companies are given several choices of developing countries where investment may be $\operatorname{put}^{2}[9]$.

The essential role for investors putting their money into foreign investment for economy development of a state requires legal systemthat provides predictable stability which is expected to become a key to a condition that supports business activities and to improve capital investment in economy. Another important factor to achieve a goal is the efficiency of legal system and its capacity to minimise business and political uncertainty along with reducing transactional expenses.

According to regional strategy designed by World Bank concerning revitalisation for mining sectors in Africa and Latin America, giving stimulus to private sectors needs to be taken into account. Moreover, privatisation of state as sents and sustainable mineral resource development are supposed to be considered as well. In this context, the legal reform is aimed to reduce real risks and other potential risks, in which the legal protection is necessary to help protect from the risks and to create more supporting atmos phere for investors. Several legal frameworks (and laws regulating investment) are proven successful to attract investors. This success is inseparable from the following factors: procedure of security of tenure and transparent and clear requirements; giving access to mineral resources; giving access to international transaction; stable and fair tax regime.

It is true that there has not been international regulation regulating guidelines regarding profit sharing in natural resources management, and sadly it is obvious that in global development, global mining indicates there is tendency for shareholders to dominate far greater profits. In addition to more as sertive regulation from each country, this condition requires more strength from the countries to which natural resources belong for greater share.

As a result, the regulation that achieves justice in mining should be based on law of each state. Indonesia, for example, makes legislation by strengthening its position to achieve the goal of mining management and for the justice and merit for all society.

In terms of achieving justice and referring to theoretical frameworks, the concept of constitution is more closely related to theoretical concept of utilitarianism. In the concept of utilitarianism, the final objective of the law or legis lation is the greatest happiness regarding the object managed. Jeremey Bentham, reporting utilitarianism mainstream, elaborates that law or legislation must put general interests above personal ones [10].

The state that holds the right to manage mining according to Article 33 Paragraph (2) and (3) of the 1945 Constitution must be pro-state. This ideology is elaborated more in Article 2 of Act concerning Mineral and Coal stating that mineral and/or coal mining is managed in accordance with: 1. Merit, justice, and balance; 2. State interest-oriented; 3. Participation, transparency, and accountability; 4. Sustainability and being environmentally sound. The principle of partis anship of a state towards state interests is explained in Act concerning Mineral and Coal, but not definition and es sence of state partis anship towards state interests. The weakness is that Act of mineral

\footnotetext{
2 Improvement of regulation concerning environment and restriction of land use in developed countries, in addition to legislation regulating investment and mining, have all brought theinvestment from west ern economy (US,
}

and coal has not held any umbrella Act that clarifies state partisanship towards state interests. In the preamble of Act regulating Mineral and Coal, there is no law serving as umbrella act regarding the supervision of implementation of Act concerning Mineral and Coal[11].

To achieve justice and social welfare, the state has regulated in its constitution regarding the guidelines so that the legislation could give certainty in regard to achieving natural resources management that leads to social justice for society, better and equal development with the constitution as the basis to achieve justice in the development and management.

Social justice in theoretical dimension as explained by John Rawls is also understood as justice in regards to how to achieve something as desired that requires efforts, benefits, and burdens in social life while it is still just for all people[12]. With this understanding, a social condition or certain social policy are regarded just or unjust when an individual or a group of particular people could only gain less profit than they should, or they are imposed with greater burden than they should[12].

Achieving social justice is essential to discuss because social justice suggests equity in terms of enjoying equally distributed portion.

\section{CONCLUSION}

There is no international rule regulating mineral or natural resources management, but the paradigm in global mining industries, investment, and profit sharing have accommodated the parties concerned to gain as much profit as possible from the state with natural resources to manage. Therefore, firm bargaining position is required for the state to maintain proportional justice, for the states own the natural resources which are supposed to be addressed to the welfare of its people and equitable development. As a result, legal product or legislation must be made appropriately for the purpose of the welfare for all people and social justice.

\section{References}

[1] HS, Salim. Hukum Pertambangan di Indonesia. Jakarta: PT. Raja Grafindo Persada, 2006.

[2] Bill Sullivan and Christian Teo Purwono \& Partners. Mining Law \& Regulatory Practice in Indonesia A Primary Reference Source. Singapore : Published by John Wiley \& Sons Singapore Pte. Ltd, 2013.

[3] Konsep Keadilan Dalam Pengelolaan dan Pemanfaatan Sumber Daya Alam Menurut Undang-Undang Pokok Araria Tahun 1960. Fatoni, M. Yazid. Nomor 1 April 2013, s.l. : Jurnal IUS, 2013, Vols. Vol I,

[4] Friedmann, Lawrence M. Legal System (A social Science Persfective), diterjemahkan oleh M.Khozim,. s.l. : Nusamedia,, 2009.

[5] Gi, The Liang. Teori-teori Keadilan. s.l. : Super, 1979.

[6] Hartono, Sunaryati. Makna Nilai-Nilai Falsafah di Dalam Pancasila Sebagai Weltanschauung Bangsa dan negara Republik Indonesia. Majalah Hukum Nasional. [Online] fle:///Users/apple/Downloads/mhn120106.pdf.

[7] Jimly Assiddiqie, "Peran Konstitusional Keadilan Sosial". Peran Konstitusional Keadilan Sosial. [Online] April 12, 2011. http://www.jimly.com/makalah/namafle/151/PESAN_KEADILAN_S OSIAL.pdf.

[8] Izin Freeport Dicabut Jika Tak Bangun Smelter dalam 5 Tahun [Online] https://tirto.id/izin-freeport-dicabut-jika-tak-bangun-smelterdalam-5-tahun-ctvM.

Canada, South Africa, and Australia) to South America and Southeast Asia. 
[9] Elizabeth Bastida, Elizabeth Bastida. Fundamentals of Mineral Law and Policy. Dundee : Centre for Energy, Petroleum \& Mineral Law \& Policy (CEPMLP), 2002.

[10] Subadi. Penguasaan Dan Penggunaan Tanaha Kawasan Hutan (Menuju Penguasaan dan Pendayagunaan Berwawasan Lingkungan, Berkelanjutan dan Berpihak Pada Kemakmuran Rakyat dalam Perspektif Otonomi Daerah). Jakarta : Prestasi Pustaka Publisher.

[11] Politik Hukum Pengelolaan Pertambangan. [Online] [Cited: August 08, 2018.]

https://www.researchgate.net/publication/308946419_Politik_Hukum_ Pengelolaan_Pertambangan_Mineral_dan_Batubara_dengan_Pendekat an_Economic_Analysis_of_Law.

[12] Miller, David. Principles of Social Justice. London : Harvard University Pres, 1999. 